\title{
ROLE OF GOLD \\ IN FOREIGN EXCHANGE RESERVES OF COMMODITY EXPORTING COUNTRIES
}

\begin{abstract}
The gold is still a reserve asset with specific features yet the variants of reserve management have improved considerably. Tendency to maintain ultra-low real interest rates potentially should affect the upward shift in demand on gold because alternative costs of holding it are declining. Demand for gold has indeed risen from the side of central banks recently. At the same time, there is no consensus in economic literature about optimal share of gold in foreign exchange reserves. However, it is presumed that incentives for more diversification are stronger than reserves hoarding is abnormal. Commodity exporters have accumulated large reserve over the last decades. Thus, their diversification decisions in favour of gold seem to be natural. However, empirical analysis paints a more complicated picture. A) Commodity exporters are getting to be more and more heterogeneous in terms holding gold as a share of foreign assets. Such heterogeneity is more vivid compared to the world as a whole. B) Distribution of gold reserves among commodity exporters is changing toward increasing number of countries with gold holdings over the median size for the group. C) There is direct correlation between global commodity prices and gold holdings in tons, but an inverse relationship in the case of share of gold in reserves. This leads to the con-
\end{abstract}

(C) Viktor Koziuk, 2021.

Koziuk, Viktor, Doctor of Economic Sciences, Professor, Head of the Department of Economic Theory, West Ukrainian National University, Ukraine. ORCID: 0000-0002-5715-2983 Email: victorkozyuk@ukr.net. 
clusion that there are two types of demand on gold: endogenous as a function of gradual hoarding of foreign exchange reserves, and specific, that is driven by specific portfolio management needs and non-economic factors. This finding is consistent with features of holding reserves in countries with large hoarding and strong vulnerability to terms-of-trade shocks and features of political regimes in countries with resource abundance.

\section{Key words:}

gold; foreign exchange reserves; foreign assets; central banks; commodity prices; commodity exporting countries.

JEL: E58, E59, O23, Q33.

8 figures, 1 table, 31 references.

\section{Introduction}

Gold has always been considered a special reserve asset. It has certain peculiarities: this asset is not someone's liability, and therefore not a financial instrument in its purest form; gold is not subject to the risk of bankruptcy or insolvency; its value is substantial in content as a physical asset, even if the price is determined by the market; gold plays the role of a hedging tool for geopolitical, geoeconomic and even security risks. On the other hand, gold as a reserve asset does not provide interest income, and therefore its contribution to the investment qualities of foreign assets of central banks as a portfolio has a number of ambiguous features. Significant fluctuations in market prices are typical for gold, as a result of which the market value of central bank reserves can both increase and decrease. Holding significant gold reserves entails significant storage costs. The opportunity cost of holding gold reserves is significant. It is affected by both the amount of storage costs and the potential return on investment in financial instruments. 
Cyclical changes in growing and declining interest from central banks in holding gold reserves can be traced. This interest does not always correspond to gold prices. There is also a relatively clear division among countries by propensity to hold gold reserves. As a rule, developed countries maintain significant gold reserves; such stocks are relatively stationary; they are not a manifestation of diversification policy, but rather a reflection of the historical trajectory of the country's foreign assets management. Other countries are quite different in terms of the share of gold in the foreign exchange reserves. Moreover, the status of a "gold-mining country" is not always the decisive factor in the structure of gold and foreign exchange reserves.

The long-term trend towards the accumulation of foreign exchange reserves in emerging markets and the advent of hoarding them has influenced the idea of what the optimal structure of central bank's foreign assets should be. Obvious spikes in commodity prices, combined with the commodity exporters' growing interest in mechanisms of ensuring macroeconomic stability, have put these countries among the number of significant hoarders of foreign exchange reserves. Based on the hypothesis that the diversification of reserves is conditional to their volume, in recent years the commodity exporters should have been inclined towards the search for options on how to go beyond treating reserves solely as factors of international liquidity. Given the medium-term trend of rising commodity prices and falling global interest rates, gold could be considered as one of the directions for diversification of foreign exchange reserves for countries prone to hoarding of foreign assets due to structural features and implemented mechanisms of macroeconomic stability. As shown by Zulaica (2020), there has recently been a clear inclination towards increasing gold reserves in the world and, in particular, in countries that do not qualify as developed. However, it remains unclear whether this trend is inherent to commodity exporters as a group of countries that can potentially be united by a common pattern of "commodity prices - significant reserves - search for options to diversify reserves - a growing share of gold in reserves». Considering the growing geopolitical tensions and nationalist-sovereign tendencies in the policies of individual countries, the confirmation or refutation of this pattern may also be an argument in favour of the confirmation or refutation of the hypothesis of non-economic drivers of demand for gold from central banks. The article considers the role of gold in the foreign exchange reserves of commodity exporters, taking into account the trends in commodity prices and changes in the distribution of indicators characterizing the accumulation of gold reserves. 


\section{Literature Review and Problem Statement}

The tendency to hoard foreign exchange reserves is quite closely scrutinised in scientific discussions (Strategy, Policy and Review Department, 2010). The motives for holding significant reserves revolve around the postulates of new mercantilism, avoiding structural reforms, smoothing productivity shocks, compensating for the insufficient efficiency of the exchange rate as a tool for adjusting to shocks in shallow financial markets, etc. (Aizenman \& Lee, 2008; Wijnholds \& Sondergaard, 2007; Pineau et al., 2006; Choi et al., 2007; Aizenman \& Riera-Crichton, 2006). The motives of self-insurance and competitive accumulation are clearly referred to in a number of studies (Aizenman \& Lee, 2007; Aizenman, 2007; Durdu et al., 2007).

Hoarding of reserves is recognized as a prerequisite for the tendency of central banks to more diversified holding of reserves (Beck \& Weber, 2010). In this context, a number of points should be noted. Summarizing the findings of a number of studies (Beck \& Weber, 2010; Ahmed et al., 2011; Goyal et al., 2011; McCauley \& Rigaudy, 2011; Morahan \& Mulder, 2013; Borio, 2008), we can see the following incentives for active reserve management, resulting in a higher level of diversification:

- larger reserves automatically mean increased fiscal losses due to increased exchange rate flexibility, and therefore more active management of foreign assets can partially offset such losses;

- large exposures involve an exacerbation of the investment value-atrisk problem;

- more active management is facilitated by the search for going beyond the standard set of reserve currencies (assets) and the growing role of multi-currency reserve assets due to the inclusion of a number of peripheral currencies in the framework of possible management of foreign assets;

- under competitive accumulation of reserves, the ability to minimize the holding losses is an important prerequisite for competitive gain, etc.

However, the most significant factor that encourages more active diversification of foreign exchange reserves is the segmentation of management motives. In the simplest terms, this means dividing reserves into a liquidity pool and an active investment management pool. The first is designed to maintain a structure that enables smoothing out fluctuations in the foreign exchange market and responding to strong global shocks. The second is meant to increase the profitability of holding the reserves and minimize the risks of fluctuations in the value of the asset portfolio (Beck \& Weber, 2010). 
However, studies on more active management of foreign exchange reserves offer no direct reservations about the special role of gold. Most likely, this is due to the cyclical sensitivity of gold prices, which means that increasing the share of gold in reserves its pure form does not guarantee the effect supposed to be achieved through the diversification of foreign assets and more active management. However, the recent upward trend in the share of gold reserves (Zulaica, 2020) requires additional attention in terms of how this fact could be affected by the tendency to accumulate significant reserves.

The studies on the peculiarities of holding reserves in gold can be clearly divided into approaches from the standpoint of asset portfolio management and approaches that take into account political and economic factors. Under any circumstances, central banks are significantly limited in their ability to diversify reserves compared to traditional portfolio managers since certain asset classes are generally not available to them due to restrictions on the reserve management profile. This explains why restrictions on the asset class in the management of foreign exchange reserves skew the choice in favour of gold.

Regarding the first approach, for example, Mendez-Barreira (2020) has noted that the medium-term downward trend in interest rates has significantly affected the reduction of alternative losses of holding large gold reserves. In combination with rising gold prices, a larger share of gold in the structure of foreign assets can be considered the best choice in terms of increasing profitability. For some countries with significant reserves denominated in euro, the shift in the composition of the portfolio of foreign assets in favour of gold may also be caused by negative interest rates.

On the other hand, the survey of central bank managers on foreign exchange reserves has shown no clear inclination towards viewing gold as a criterion for a significant change in the composition of foreign assets. At the same time, the reasons for choosing gold indicated most often included the benefits of diversification (64\% of respondents), low interest rates (41\%), and the contribution to portfolio risk assessment (36\%). A smaller, though not insignificant, share of respondents (32\%) recognized international geopolitical challenges as important for this. Moreover, most respondents believe that the share of gold in reserves should be within $10 \%$, while only $18 \%$ would allow the share to increase to $10-19 \%$ and $20-49 \%$ each. Almost no one considers the optimal share of gold to be more than $50 \%$ of reserves (Carver \& Pringle; 2020). Taking into account that since 2007 the volume of gold reserves in tons has not changed in developed countries (about 23 thousand tons), and increased by 5 thousand tons in the rest of the world (Central Banking, 2020), we can assume that the precious metal receives more attention in the process of managing foreign assets if the reserves are being increased. This is strengthened by the fact that the nominal and real yield of gold in times of recession shows better indicators than other classs of reserve assets, even if the calculations for 1973-2019 imply the predominance of financial instruments issued in the United States (Central Banking, 
2020). This confirms that there is no cyclical neutrality to holding gold. However, in the context of the large-scale crisis of 2020-2021 and the fight against its consequences, increasing the share of metal reserves may seem natural, despite the fact that some countries have sold some gold reserves in order to better combat the effects of the pandemic.

More sophisticated among techniques for assessing the effectiveness of portfolio management also show mixed results. The share of gold in reserves has a certain optimal final value due to the market risk associated with gold. This is indicated by a set of investment criteria, namely prevention of portfolio volatility, risks of unlikely but severe shocks (tail risks), probability of losses, and criteria for diversification. At the same time, a larger share of gold may also be justified in certain specific cases. This is the case when reserves are sensitive to the duration risk, or when the return on reserves is not determined in traditional reserve currencies (Zulaica, 2020). In other words, the choice of reserve management criteria can determine the tendencies of central banks when deciding on their optimal composition in terms of asset class. For example, criteria based on standard portfolio theory will show a different optimal share of gold than approaches based on the concept of value-at-risk (for more details, these opposing positions are presented by Zulaica (2020), Baur and McDermott (2010), and Reboreddo (2013)).

Political and economic factors in the management of foreign exchange reserves create a different view of this problem. For example, a number of papers point out that there are excellent motives for hoarding reserves in the context of democracies and autocracies, and the concentration of exports can significantly affect the incentives for hypertrophy of foreign assets (Jager, 2016; Son, 2020; Leblang \& Pepinsky, 2008). In other words, the political regime is a factor influencing the amount of reserves. For example, Koziuk (2016a) shows the relationship between the political regime, financial development and the size of reserves in the context of heterogeneity of commodity economies, which may form quite different patterns of institutional quality relevant to the chosen modality of adaptation to macroeconomic shocks. Given that commodity exporters are often autocracies, the political motives for choosing the structure of foreign assets cannot be ignored.

In turn, gold is seen as a specific asset class, the prices of which are determined by geopolitical factors; while such prices can affect the motivation to hold large gold reserves, the latter, in turn, pushes metal prices up. In addition, historically, gold retains the role of "safe haven" in times of geopolitical tensions or outright conflicts (Bahrami Moghadam \& Baghernia, 2020). Analysis of the currency structure of foreign assets indicates that geopolitical factors influence the choice of central banks, thereby confirming that the political and economic aspects of foreign asset management cannot be ignored (Eichengreen et al., 2017). 
Empirical analysis of gold reserves also confirms the importance of the historical trajectory. For example, the size of gold reserves is a reflection of the global power of the country, its geopolitical capacity and international respect it commands. The status of a former empire as well as the issuance of reserve currency are factors that determine larger shares of gold in reserves. On the other hand, the requirements central banks must adhere to concerning the size of gold reserves reflect the efforts to avoid significant losses associated with fluctuations in metal prices (Aizenman \& Inoue, 2013). Central bankers' risk aversion may seem like a purely technical issue, but it stems from a political assessment of losses from holding reserves and therefore becomes an institutional incentive to self-limit the choice of asset classes through which diversification is implemented (Aizenman \& Marion, 2003). Active management of reserves as a result of their hoarding does not necessarily affect the physical volume of gold. For the most part, it is under passive control (Aizenman \& Inoue, 2013). It follows that even if the size of reserves affects the motivation to manage them more actively, as predicted by Beck and Weber (2010), this does not necessarily mean that gold will represent the asset class through which such proactive management will be carried out.

Research shows that with significant reserves, the likelihood that the role of gold will increase is obvious, but this does not correspond so clearly to a more proactive approach to foreign asset management. Thus, countries with resource abundance are likely to use a more sophisticated model of reserves management when making the choice in favour of gold.

The article suggests that for commodity economies there must be some connection between commodity prices and the shift towards holding larger gold reserves. If such a relationship is direct and significant, it will mean that such countries diversify foreign assets in favour of gold while increasing reserves during the commodity boom. If the relationship is weak or inverse, gold will not play a significant role in adapting the structure of reserves to a positive price shock. The article also aims to analyse changes in the distribution of indicators of gold reserves in tons, gold as a share of total reserves and reserves to GDP in 53 commodity exporters compared to the world as a whole. These 53 countries are identified in the IMF study based on the relevant methodology (International Monetary Fund, 2015).

\section{Empirical overview of the tendency to hoard gold reserves}

Hoarding of reserves has grown into a problem of global monetary and macrofinancial stability due to significant volumes of foreign assets. A limited number of countries hoarding gold and active management of foreign assets 
highlight a number of risks that threaten to destabilize global finance in the event of significant changes in the structure of central bank assets (Koziuk, 2016b). Several commodity exporters are among the top ten countries with the largest reserves (for example, Norway, Russia, Saudi Arabia, Algeria).

Although the general tendency of hoarding reserves that has emerged since 2015 does not seem to be as dramatic as it used to be before the global financial crisis, it is clear that the underlying global trend of increasing the ratio of external central bank assets to GDP remains (Fig. 1). It is no longer exponential, as it was before 2008, but after the rapid recovery of the global economy in 20112012, the hoarding of reserves as a percentage of GDP has slowed significantly. The corresponding indicator for 53 commodity exporters clearly shows a higher level of volatility: faster growth before the global financial crisis, instability after it and a gradual decline against the backdrop of falling commodity prices since 2014 (Fig. 1).

Figure 1

\section{Ratio of foreign exchange reserves to GDP}

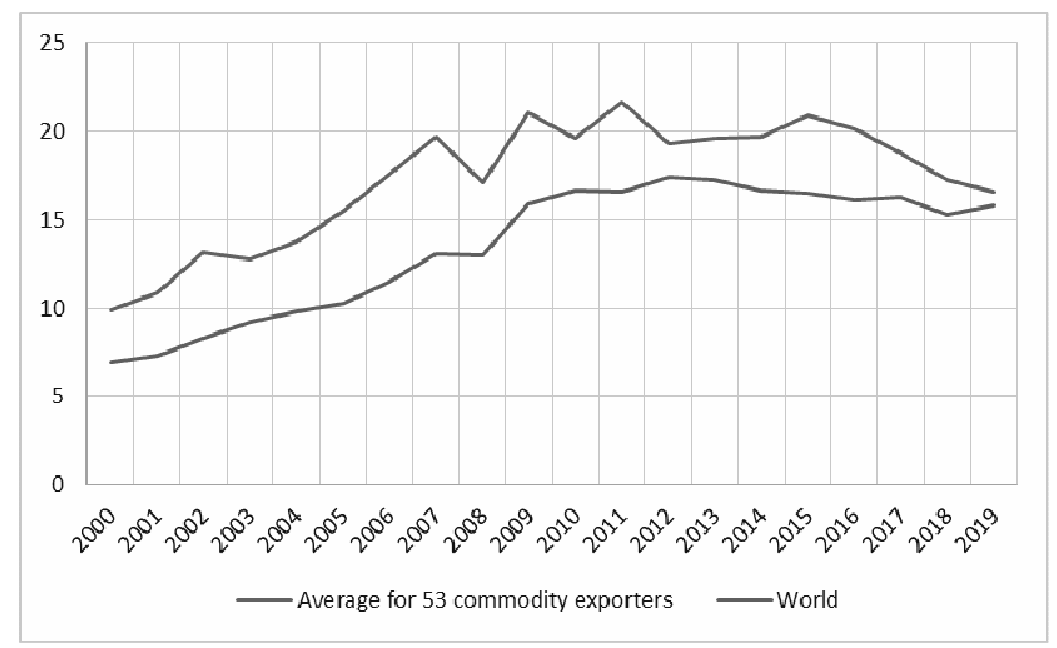

Source: calculated by the author using the data of International Monetary Fund.

Fig. 2 shows that there is a clear link between the trends in global commodity prices and the hoarding of reserves by resource-rich countries. It should 
be noted that the logarithmic approximation function has slightly better characteristics than the linear one. This suggests that there is no automatic transfer of commodity prices to reserves. That is, macro-policy bodies search for additional options to respond to strong positive shocks in commodity prices, combining appropriate tools. Strengthening the exchange rate is likely to be one of them. The relationship between commodity prices and hoarding of reserves confirms that commodity exporters are quite severely impacted by terms-of-trade shocks, which should in theory maintain the balance between liquidity and the benefits of diversifying foreign exchange reserves.

Figure 2

\section{Global commodity prices and hoarding of foreign exchange reserves} by commodity exporting countries

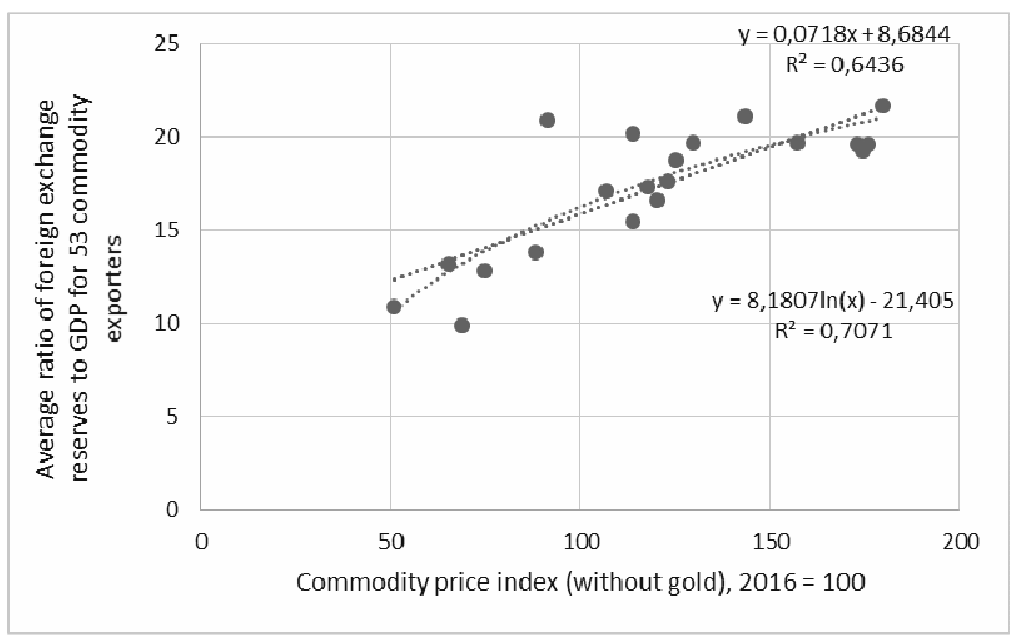

Source: calculated by the author using the data of International Monetary Fund and World Gold Council.

The vulnerability of resource-rich countries to terms-of-trade shocks raises the question of the optimal structure of foreign assets. Recently, the global economy has faced a clear upward trend in commodity prices, going through three peaks in 2008, 2011 and 2021. Responding to this by avoiding a significant strengthening of exchange rates should encourage a larger share of reserves that need to be diversified. At the same time, the pro-cyclical nature of commodity prices is especially evident in the context of the increasing financial openness 
of many commodity exporters. The need to smooth out not only price shocks but also capital flow shocks should mean that the relevant central banks cannot rely solely on the criterion of maximizing portfolio returns. The need to maintain significant amounts of liquid reserves should potentially reduce interest in the role of gold as a key driver of foreign asset management. The well-known fact of close correlation between commodity prices and gold prices can both precipitate an increase in the share of metal and encourage a more restrained assessment of its role in ensuring compliance with selected criteria for the effectiveness of reserves management. However, there has been a recent tendency of metal prices to outpace the aggregate commodity price index, indicating that the gold market is developing an autonomous trend towards equilibrium that is not related to the commodity cycle.

Figure 3

\section{Price of gold and commodity prices}

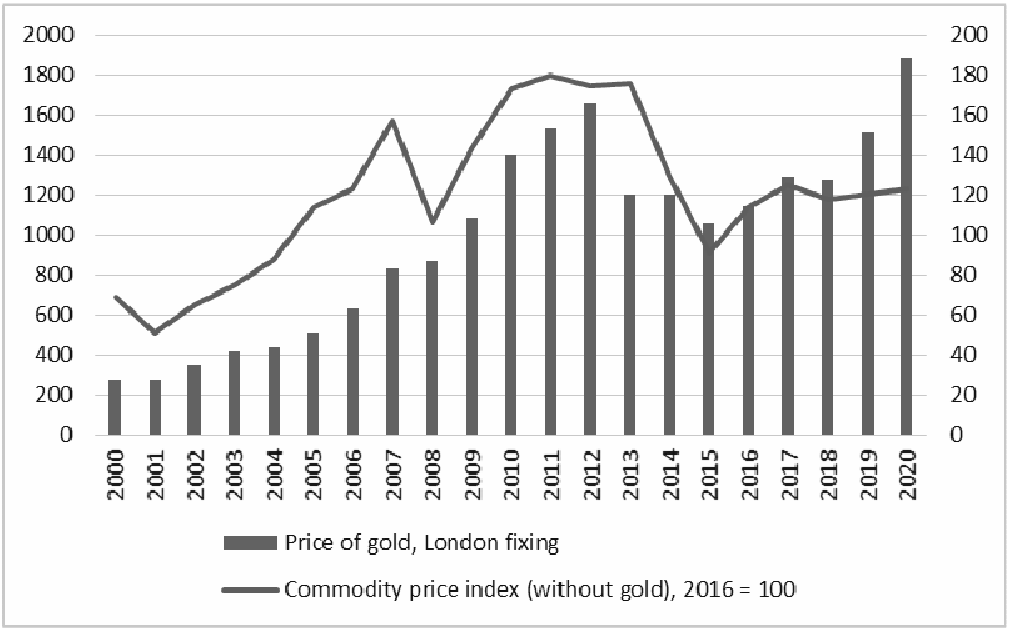

Source: calculated by the author using the data of International Monetary Fund and World Gold Council.

The data in Figures 4-8 paint a rather ambiguous picture of the role of gold in the structure of foreign exchange reserves of commodity exporting countries. For instance, data depicted in Fig. 4 makes it obvious that the global financial crisis has proved to be a watershed for the hoarding of gold reserves. While before 
2008 there was a clear trend for the world as a whole of reducing gold reserves in tons, it completely changed to the opposite after. For 53 countries, gold reserves in tons were almost unchanged until 2007, after which they began to grow, slowing down over the past year. However, the growth rate of gold reserves in tons (Fig. 5) is different. While the growth rate is relatively uniform worldwide, the indicators of commodity exporters are characterized by clear volatility. Moreover, the peak acceleration of the rate of gold reserves accumulation was achieved prior to the global financial crisis, whereas since 2018 there has been a decline in this indicator.

Figure 4

\section{Accumulation of gold reserves, tons}

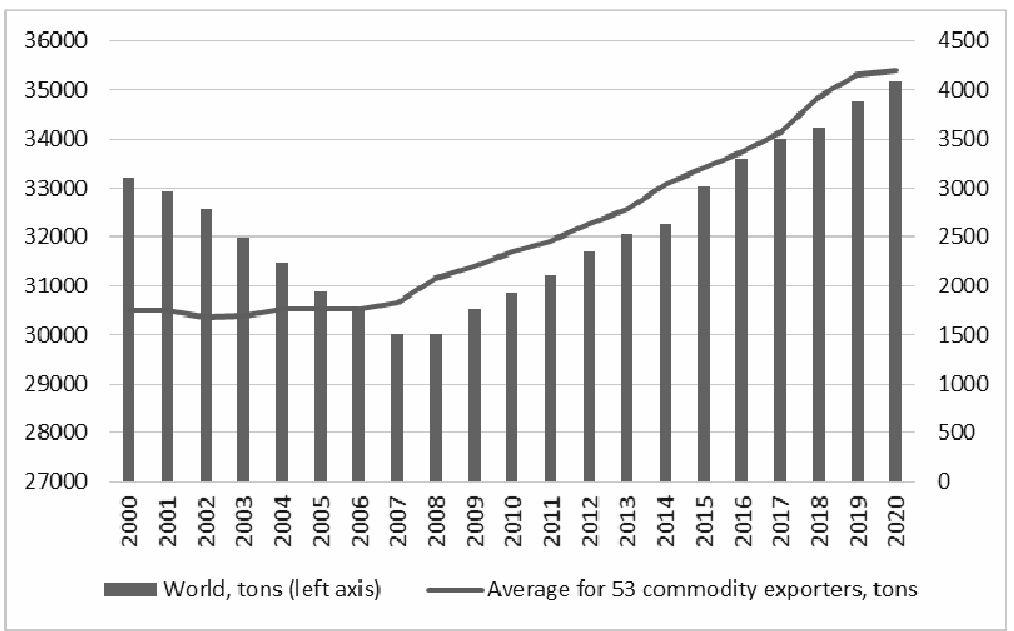

Source: calculated by the author using the data of World Gold Council.

Fig. 6 highlights the direct linear relationship between the changes in commodity prices and demand for gold reserves from resource-rich countries, which may be the confirmation of the hypothesis concerning the role of gold in the diversification of foreign assets of central banks. However, the significance of this relationship is not sufficient to argue that gold itself is the means of the diversification of foreign exchange reserves, whose accumulation is facilitated by commodity prices. 
Figure 5

Growth rate of gold reserves (in tons) worldwide and in commodity exporting countries

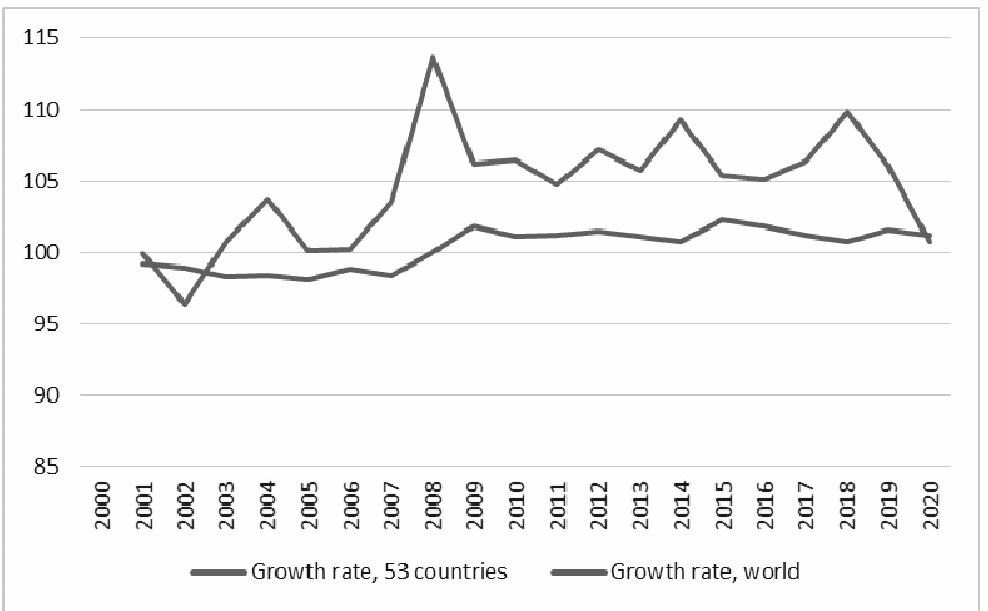

Source: calculated by the author using the data of World Gold Council.

\section{Figure 6}

Global commodity prices and growth of gold reserves in commodity-exporting countries

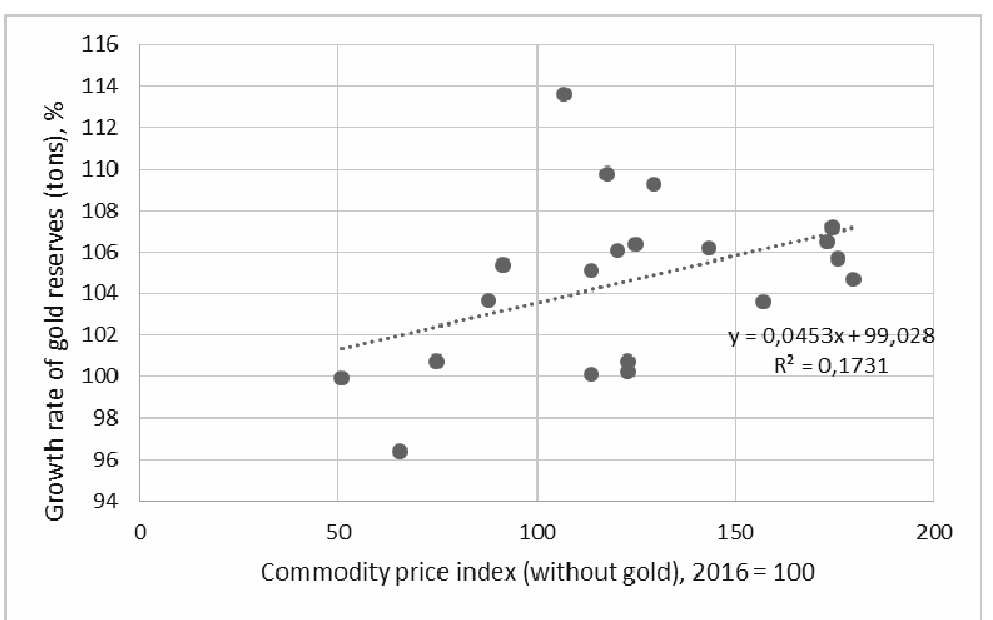

Source: calculated by the author using the data of International Monetary Fund and World Gold Council. 
The dynamics of the share of gold in the foreign exchange reserves indicates that the link between commodity prices and diversification is not always obvious. In particular, Fig. 7 shows that the global trend towards the choosing gold in the structure of foreign exchange reserves is generally replicated by the commodity exporting countries. There have only been some differences in the last two years. However, the data of Fig. 8 indicate that the relationship between this share and the changes in commodity prices is inverse. At first glance, this contradicts the data in Fig. 6, but this is explained by the fact that the increase in the share of gold is significantly outpaced by the maximum increase in total reserves caused by the positive shock of commodity prices.

There are three conclusions that can be drawn from this trend in terms of reserves management.

First, there is an endogenous demand for gold, which is in some way tied to the general process of hoarding reserves. If the latter is determined by price trends, so will be the motives behind the demand for gold.

Second, diversification in favour of gold is not a automatic consequence of such endogenous demand. Additional incentives are needed for decisions on changes to the composition of reserves. Their adoption may not always coincide with the global commodity cycle. Alternatives to diversification may at times be more attractive.

Figure 7

\section{Average value of the share of gold in foreign exchange reserves}

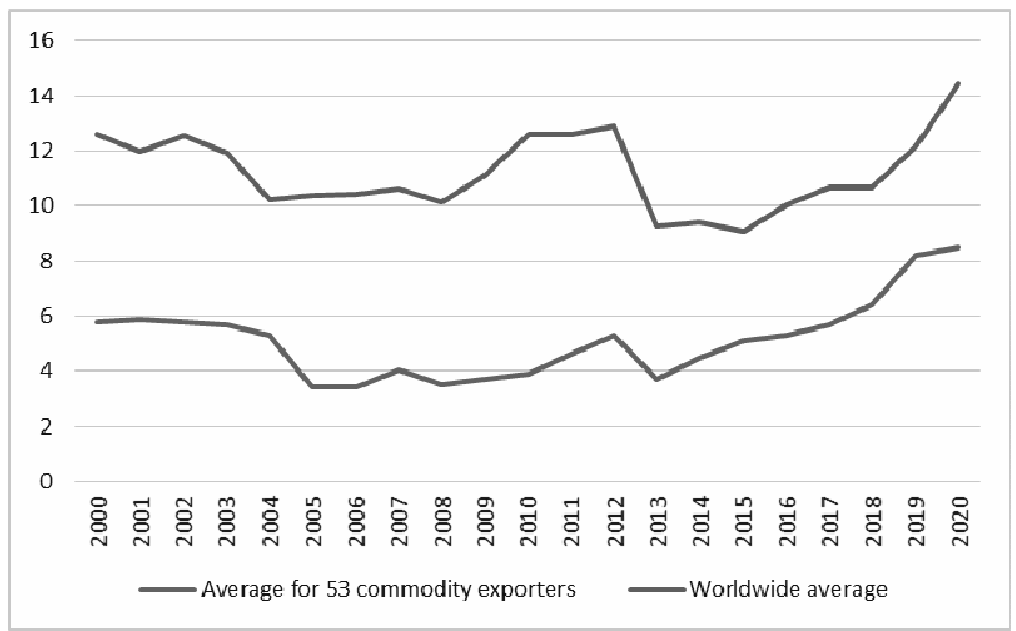

Source: calculated by the author using the data of World Gold Council. 
Figure 8

\section{Commodity prices and the share of gold in foreign exchange reserves in commodity exporting countries}

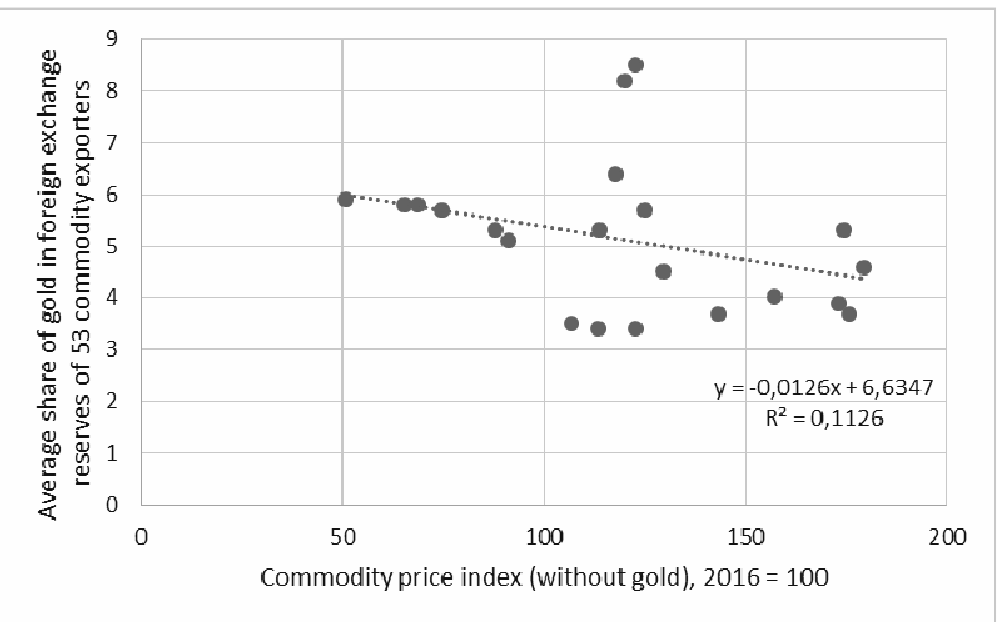

Source: calculated by the author using the data of International Monetary Fund and World Gold Council.

Third, the choice to diversify reserves through gold entails consideration of the more complex links between the expected changes in commodity prices, accumulation of reserves, and possible division of the latter into liquidity and investment component. In other words, expectations about the stability of the future price trend determine the ratio between the liquid and investment part of reserves, which brings to forefront the importance of choosing the composition of reserves that meets the criteria for managing the portfolio of foreign assets. For example, if the forecast projects a steady rise in commodity prices accompanied by low interest rates, diversification through gold may meet a wide range of criteria for the investment portfolio of central bank foreign assets. Conversely, when commodity price volatility is expected along with uncertainty about global demand for commodities, diversification through gold may not meet the criteria for effective management even in case of growing reserves.

In addition, drivers of currency inflows may matter for commodity exporters. Since the commodity price cycle and the capital inflow cycle are fairly synchronized in resource-rich countries, the motives for expanding gold reserves may be determined by how stable the source of foreign exchange is. The relationship between commodity prices and gold reserves in tons is opposite to that 
between commodity prices and the share of gold in reserves. This can be explained by the fact that if the capital flows are perceived as volatile, it significantly complicates the criteria for optimal management of foreign assets.

Let it not be forgotten that both the demand for gold and fluctuations in commodity prices respond to geopolitical factors. The heterogeneity of political regimes and the exported resources makes commodity exporters very sensitive to geopolitical tensions. For example, oil prices tend to be more sensitive to them, and most energy exporters are autocracies in which demand for gold can be a tool for maintaining the stability and independence of the political regime from external pressures. Metal prices are more closely tied to the global construction cycle, and metal exporters themselves are less vulnerable to confrontations between countries with different perceptions of the global good and national interests. Agricultural exporters are more sensitive to weather shocks, on the one hand, and to long-term changes in the nature of food consumption, on the other. They may be less dependent on the terms-of-trade shocks introduced by geopolitical factors.

\section{Uneven distribution of gold reserves}

Differences in the political and economic structures of commodity economies increase the likelihood that their ability to both accumulate reserves and have an incentive to increase the share of gold in them may differ significantly. The degree of heterogeneity of resource-rich countries as a group was determined using a formal assessment of the characteristics of the distribution of three indicators: foreign exchange reserves (excluding gold) as percentage of GDP, gold in tons, and the share of gold in foreign exchange reserves. The calculated values of asymmetry, excess and standard deviation ratios for the world as a whole and a sample of 53 commodity exporters (Table 1) enable a comparison of how the analysed countries differ in terms of heterogeneity of policies for the management of external central bank assets. Formal assessment of the statistical characteristics of the distribution through the years allows us to see a clear trend towards increasing heterogeneity in the management of foreign exchange reserves, which highlights the fact that commodity exporters appear to be a more homogeneous group than the world as a whole.

Several conclusion can be drawn by analysing the calculation results of the statistical properties of the distribution. First, the ratio of reserves to GDP for the world as a whole tended to be more evenly distributed before the global financial crisis, after which the trend reversed and became less stable. Moreover, although the peak of uneven distribution was recorded in 2015 and afterwards the unevenness decreased slightly, it did not return to the level of the global financial crisis. 
Table 1

Statistical assessment of the distribution of foreign exchange reserves to GDP, the share of gold in the foreign exchange reserves and gold reserves in tons

\begin{tabular}{|l|l|c|c|c|c|c|}
\hline \multicolumn{2}{|c|}{} & 2000 & 2004 & 2007 & 2015 & 2020 \\
\hline \multirow{2}{*}{$\begin{array}{l}\text { All countries, gold, } \\
\text { tons }\end{array}$} & Asymmetry & 9,9 & 9,8 & 9,78 & 10,0 & 10,1 \\
\cline { 2 - 7 } & Excess & 103,5 & 102,5 & 101,4 & 105,0 & 106,4 \\
\cline { 2 - 7 } & $\begin{array}{l}\text { Standard } \\
\text { deviation }\end{array}$ & 3103,6 & 2950,2 & 2820,4 & 3068,0 & 3257,1 \\
\hline \multirow{2}{*}{$\begin{array}{l}\text { All countries, gold } \\
\text { as \% of foreign ex- } \\
\text { change reserves }\end{array}$} & Asymmetry & 2,2 & 2,4 & 2,7 & 2,5 & 1,9 \\
\cline { 2 - 7 } & $\begin{array}{l}\text { Excess } \\
\text { Standard } \\
\text { deviation }\end{array}$ & 12,6 & 5,3 & 6,7 & 5,5 & 2,7 \\
\hline $\begin{array}{l}\text { All countries, for- } \\
\text { eign exchange re- } \\
\text { serves as \% of }\end{array}$ & Asymmetry & 3,1 & 2,7 & 2,6 & 5,4 & 3,3 \\
\cline { 2 - 7 } GDP & $\begin{array}{l}\text { Excess } \\
\text { Standard }\end{array}$ & 14,2 & 9,1 & 8,6 & 38,7 & 13,9 \\
\hline \multirow{2}{*}{$\begin{array}{l}53 \text { countries, gold, } \\
\text { tons* }\end{array}$} & Asymmetry & 3,0 & 16,1 & 19,5 & 31,3 & 23,7 \\
\cline { 2 - 7 } & Excess & 9,5 & 9,8 & 11,8 & 34,0 & 39,1 \\
\cline { 2 - 7 } & $\begin{array}{l}\text { Standard } \\
\text { deviation }\end{array}$ & 81,6 & 85,3 & 91,3 & 219,7 & 349,3 \\
\hline \multirow{2}{*}{$\begin{array}{l}53 \text { countries, gold } \\
\text { as \% of foreign ex- } \\
\text { change reserves* }\end{array}$} & Asymmetry & 3,4 & 3,8 & 4,0 & 5,2 & 2,8 \\
\cline { 2 - 7 } & $\begin{array}{l}\text { Excess } \\
\text { Standard } \\
\text { deviation }\end{array}$ & 15,1 & 17,3 & 19,8 & 30,3 & 8,2 \\
\hline $\begin{array}{l}53 \text { countries, for- } \\
\text { eign exchange re- } \\
\text { serves as \% of } \\
\text { GDP* }\end{array}$ & Asymmetry & 1,1 & 2,7 & 2,7 & 4,8 & 4,4 \\
\cline { 2 - 7 } & Excess & 1,4 & 8,99 & 8,3 & 26,0 & 22,2 \\
\cline { 2 - 7 } & $\begin{array}{l}\text { Standard } \\
\text { deviation }\end{array}$ & 7,7 & 15,2 & 23,1 & 45,0 & 26,5 \\
\hline
\end{tabular}

Note*: 53 commodity exporters were chosen according to International Monetary Fund (2015). World economic outlook: Adjusting to lower commodity prices.

Note: calculated by the author using the STATISTICA software based on IMF and World Gold Council data.

This may indicate that in the period characterized by the greatest expansion of foreign assets of central banks, monetary authorities accumulate them relatively evenly, but in periods of volatility of foreign assets, the loss / accumulation is uneven. The same trend is quite clear in the case of commodity exporters. In both cases, it is interesting that an increase in the standard deviation of the reserve ratio to GDP was combined with a decrease in the coefficients of asymme- 
try and excess prior to the global financial crisis. This indicates that there were two coexisting trends: increased homogeneity in the accumulation of reserves where their ratio to GDP was close to the median, and an increase in the number of countries with concentrated reserves in volumes that were unattainable for most countries. After the global financial crisis, the situation changed to the opposite. For both groups of countries there is a decrease in the standard deviation from the peak values in 2015 to slightly higher than the previous period in 2020 , along with a decrease in the coefficients of asymmetry and excess for the same period. This indicates that the distribution curve has flattened and shifted to the right. In other words, the share of countries with reserves in excess of the median value has increased. Such changes in the distribution may suggest that if before the crisis a very limited number of countries with concentrated reserves could be prone to more active diversification, in particular in the direction of gold, then later such behaviour could be used by many more countries, but not on such a large scale.

Second, statistics show that there has indeed been an increase in demand for gold in countries that were actively accumulating reserves. In particular, the world indicator of gold in tons is characterized by slight changes in the statistical characteristics of the distribution without a clear trend although the uneven distribution has generally increased, which can be seen from all three indicators. The coefficients of asymmetry, excess and standard deviation increased simultaneously at the end of the period. However, for a sample of 53 countries, this trend has been observed throughout the twenty-year period and is much clearer. All three indicators of the statistical distribution increased in value. On the one hand, this is evidence of an increase in the number of countries with roughly median gold holdings. On the other hand, the uneven distribution is observed in the "tail" zone of the distribution curve, i.e. heterogeneity is determined by the countries that have hoarded more gold reserves while the number of countries with similar shares of gold in foreign assets has increased. Taking into account the connection described above between the increase in reserves and the demand for metal by central banks, we can confirm the assertion of endogenous motives for the increase in gold in the reserves of monetary authorities. Such endogeneity, although not an automatic continuation of the accumulation of foreign assets, is clearly observed where there is a tendency to move from median holdings to concentrated ones. Concentrated holdings generally lead to additional incentives for diversification, making gold a possible option for a more sophisticated portfolio approach to foreign asset management.

Third, despite the fact that distribution of gold in tons indicates the likelihood of a growing role of the metal as a way to build a more sophisticated portfolio of foreign assets, the distribution of gold's share in reserves indicates ambiguous processes. For the world as a whole, changes in the distribution are inclined towards the increasing heterogeneity of countries in terms of gold's share in the reserves. The distribution curve simultaneously flattens and shifts to the left as the standard deviation increases. In other words, the world as a whole is charac- 
terized by significant variations in the role of metal in the structure of reserves. This underscores the assertion that there are excellent motives for managing a portfolio of foreign assets and that such motives may go beyond purely economic considerations. The situation is less clear when it comes to commodity exporters. Until 2015, the number of countries with a share of gold in reserves close to the median value tended to increase, as did the number of countries with a clear advantage in terms of holding a significant share of gold reserves. However, since then the situation echoed the worldwide trend - the distribution curve flattened and shifted to the left. In other words, the uneven distribution worsened (the standard deviation of gold's share in reserves was increasing from 2015 to 2020) due to deviations from the median values. The relatively high volatility of commodity prices during this period influenced the differentiation of incentives to determine the optimal share of gold in reserves in terms of many resource-rich countries. This confirms the existence of two coexisting motives behind the demand for metal - endogenous (determined by the size of reserves) and induced (determined by the aspiration for more sophisticated management of the foreign assets portfolio when reserves are sufficiently concentrated). The more commodity economies differ in their ability to accumulate reserves (due to the role of foreign assets in maintaining both macroeconomic and political stability), the more they will differ in the tendency to determine the optimal share of gold in the reserves adjusted for endogenous metal demand.

The specific relationship between the demand for gold from commodity exporters and commodity prices has a number of implications for global macrofinancial processes. For one, there will certainly be no strong effects of concentration. That is, a few players are unlikely to be able to significantly influence the modality of yield in the gold market. At the same time, additional market volatility may be brought on by a significant number of countries with a fairly significant potential demand for gold but no pronounced portfolio shift in its favour. This can be explained by the fact that the probability of significant increase in the demand for gold for the purposes of diversifying the reserves and maintaining a certain level of endogenous demand will be distributed roughly equally for such countries, which will make it difficult to predict the market conditions. In turn, such uncertainty about the demand for gold as a reserve asset may spill over to some other segments of the global financial market in the form of volatility (the effects of the transition to more active management of central bank reserves are described by Koziuk (2016b)). The shift in demand from one asset class to another can be palpable. The ability to predict such shifts will also be limited. 


\section{Conclusions}

Peculiarities of gold as a reserve asset have long drawn the attention of central banks. The long-term downward trend in global real interest rates potentially creates the preconditions for increasing demand for gold, as the opportunity costs of holding it decrease. Theoretically, there is some uncertainty about the optimal share of gold in the structure of foreign exchange reserves. The issues concerning the criteria for managing the portfolio of foreign assets that take into account the peculiarities of price dynamics in the gold market also remain under scrutiny. Economic science does not rule out non-economic factors in the management of central bank reserves, in particular, this applies to gold as a tool for hedging geopolitical risks.

In light of the medium-term upward trend in commodity prices, resourcerich countries have significant foreign assets. Their central banks could potentially be considered the largest contributors to global demand for gold, in particular for reasons of greater diversification of reserves as the latter are hoarded. However, empirical analysis of a number of indicators of foreign exchange reserves worldwide and for a group of commodity exporters does not indicate that diversification by gold is undeniable. On the one hand, the demand for the metal is positively correlated with changes in global commodity prices. On the other hand, the share of gold in the reserves of central banks of commodity-rich countries does not show the same direct relationship with commodity prices. Together with the distribution of the chosen indicators on the volume and structure of foreign exchange reserves, this indicates that there is a so-called endogenous demand for gold tied to the general trend of increasing reserves, as well as demand for gold determined by specific motives. At the same time, commodity exporters are more heterogeneous in terms of gold holdings than the world as a whole. The tendency to uneven distribution of gold reserves is accompanied by an increase in the number of countries whose metal reserves exceed the median value. For global macrofinance, this has some significance: volatility in reserve asset markets can be brought about by unpredictable changes in the criteria for maintaining the optimal structure of central bank reserves by a significant number of countries.

\section{References}

Ahmed, M. F., Wang, M. S., y Lago, M. I. M., Maziad, S., Segal, S., Farahmand, P., \& Das, M. U. S. (2011). Internationalization of emerging market currencies: a balance between risks and rewards. International Monetary Fund. https://www.imf.org/external/pubs/ft/sdn/2011/sdn1117.pdf 

of commodity exporting countries

Aizenman, J. (2007). Large hoarding of international reserves and the emerging global economic architecture. NBER Working paper, No. 13277. https://www.nber.org/system/files/working_papers/w13277/w13277.pdf

Aizenman, J., \& Inoue, K. (2013). Central banks and gold puzzles. Journal of the Japanese and International Economies, 28, 69-90. https://doi.org/10.3386/ w17894

Aizenman, J., \& Lee, J. (2008). Financial versus monetary mercantilism: Longrun view of large international reserves hoarding. World Economy, 31(5), 593-611.

Aizenman, J., \& Lee, J. (2007). International reserves: Precautionary vs. Mercantilist views, theory and evidence. Open Economies Review, 18(2), 191214. https://doi.org/10.1007/s11079-007-9030-z

Aizenman, J., \& Marion, N. (2003). The high demand for international reserves in the Far East: What is going on?. Journal of the Japanese and International Economies, 17(3), 370-400.

Aizenman, J., \& Riera-Crichton, D. (2006). Real exchange rate and international reserves in the era of growing financial and trade integration. NBER Working Paper, No. 12363. https://www.nber.org/system/files/working_papers/ w12363/w12363.pdf

Bahrami Moghadam, S., \& Baghernia, N. (2020). The political economy of gold in geo-economic evolving conditions. Geopolitics Quarterly, 16(60), 209-233.

Baur, D. G., \& McDermott, T. K. (2010). Is gold a safe haven? International evidence. Journal of Banking \& Finance, 34(8), 1886-1898.

Beck, R., \& Weber, S. (2010). Should larger reserve holdings be more diversified?. ECB Working Paper Series, No. 1193. https://www.ecb.europa.eu/ pub/pdf/scpwps/ecbwp1193.pdf

Borio, C., Galati, G., \& Heath, A. (2008). FX reserve management: Trends and challenges. BIS Papers, No. 40. https://www.bis.org/publ/bppdf/ bispap40.pdf

Carver, N., \& Pringle, R. (2020, Nov 10). Gold reserves in Central Banks - 2020 survey results. Central Banking. https://www.centralbanking.com/centralbanks/reserves/gold/7706776/gold-reserves-in-central-banks-2020-surveyresults

Central Banking. (2020, Nov 10). All that glitters - surveying Central Banks on gold reserves. https://www.centralbanking.com/central-banks/reserves/ gold/7706256/all-that-glitters-surveying-central-banks-on-gold-reserves

Choi, W. G., Sharma, S., \& Stromqvist, M. (2007). Capital flows, financial integration, and international reserves holding: the recent experience of emerging market and advanced economies. IMF Working Paper. WP/07/151. 
https://www.imf.org/-/media/Websites/IMF/imported-full-text-pdf/external/ pubs/ft/wp/2007/_wp07151.ashx

Durdu, C. B., Mendoza, E., \& Terrones, M. (2007). Precautionary demand for foreign assets in sudden stop economies: An assessment of the New Merchantilism. IMF Working Paper, WP/07/146. https://www.imf.org/external/ pubs/ft/wp/2007/wp07146.pdf

Eichengreen, B., Mehl, A., \& Chitu, L. (2017). Mars or Mercury? The geopolitics of international currency choice. NBER Working Paper No. 24145. https://doi.org/10.3386/w24145

Goyal, R., Marsh, C., Raman, N., Wang, S., \& Ahmed Hannan, S. (2011). Financial deepening and international monetary stability. International Monetary Fund. http://dx.doi.org/10.5089/9781463925987.006

International Monetary Fund. (2015). World economic outlook: Adjusting to lower commodity prices.

Jager, K. (2016). The role of regime type in the political economy of foreign reserves accumulation. European Journal of Political Economy, 44, 79-96. http://dx.doi.org/10.1016/j.ejpoleco.2016.05.001

Koziuk, V. (2016a). Financial development, forex reserves and political regimes in resource rich economies [in Ukrainian]. Economic Theory, 3, 82-102.

Koziuk, V. (2016b). Preconditions and global macrofinancial effects of the active portfolio management of currency reserves [in Ukrainian]. Economy of Ukraine, 6, 40-60.

Leblang, D., \& Pepinsky, Th. (2008). To have or to hoard? The political economy of international reserves. 2008 Annual Meetings of the American Political Science Association.

McCauley, R. N., \& Rigaudy, J. F. (2011). Managing foreign exchange reserves in the crisis and after. BIS Papers, 58, 19-47.

Mendez-Barreira, V. (2020, Nov 10). The ultimate store of value. Central Banking. https://www.centralbanking.com/central-banks/reserves/gold/7711621/ the-ultimate-store-of-value

Morahan, A., \& Mulder, M. C. B. (2013). Survey of reserve managers: lessons from the crisis. IMF Working Papers, 13(99). http://dx.doi.org/ $10.5089 / 9781484308486.001$

Pineau, G., Dorrucci, E., Comelli, F., \& Lagerblom, A. (2006). The accumulation of foreign reserves. ECB Occasional Paper, No. 43. https://www.ecb.europa.eu/pub/pdf/scpops/ecbocp43.pdf

Reboredo, J. C. (2013). Is gold a safe haven or a hedge for the US dollar? Implications for risk management. Journal of Banking \& Finance, 37(8), 26652676. https://doi.org/10.1016/j.jbankfin.2013.03.020 
Son, B. (2020). Democracy and reserves. Foreign Policy Analysis, 16(3), 417437. https://doi.org/10.1093/fpa/orz020

Strategy, Policy and Review Department. (2010). Reserve accumulation and international monetary stability. IMF. https://www.imf.org/external/np/pp/ eng/2010/041310.pdf

Wijnholds, O., \& Sondergaard, L. (2007). Reserve accumulation: Objective or byproduct? ECB Occasional Paper. No.73. https://www.ecb.europa.eu/ pub/pdf/scpops/ecbocp73.pdf?a3acef9a172a28317b092403bef88324

Zulaica, O. (2020). What share for gold? On the interaction of gold and foreign exchange reserve returns. BIS Working Paper, No. 906.

Received: April 11, 2021.

Reviewed: April 18, 2021.

Accepted: April 20, 2021. 